\title{
Technological Innovations in Muccoadhessive Gastroretentive Drug Delivery System (MGRDDS)
}

\author{
Ruby Saini ${ }^{1}$, Gyati Shilakari Asthana ${ }^{1,2}$ and Abhay Asthana ${ }^{1 *}$ \\ ${ }^{1}$ MM College of Pharmacy, MM University, India \\ ${ }^{2}$ College of Pharmacy, Bharat Institute of Technology, India
}

Submission: April 25, 2017; Published: May 30, 2017

"Corresponding author: Abhay Asthana, MM University, Mullana, Amabala, India, Email: abhaypharmacy@gmail.com

\begin{abstract}
Pharmaceutical industries have shown much interest in the design and development related to oral drug delivery systems. Oral administration of the drug seems to be most convenient, non-invasive and cost effective. Hence, MGRDDS seems to be a major breakthrough in the field of oral delivery of drug candidates with compromised bioavailability utilizing site specific drug delivery. This technology aids in continuous or sustained release of drug by their tendency to adhere to the mucus lining of GIT, hence are safeguarded against gastric emptying ensuring optimal bioavailability. This review article has been written with a purpose of providing insight regarding theoretical considerations of formulating MGRDDS
\end{abstract}

Keywords: Oral route; Muccoadhesive gastroretentive drug delivery systems (MGRDDS); gastrointestinal tract (GIT)

\section{Introduction}

Oral sustained drug delivery system faces challenges due to limited gastroretention time during rapid gastrointestinal transit, can prevent complete drug release in the absorption zone and reduces the efficacy of the administered dose, since majority of drugs are absorbed in stomach or non-specific location in small intestine [1,2]. Formulating mucoadhesive dosage forms is one of the key approaches to overcome issues related to gastric emptying time, as gastric mucoadhesion is the phenomenon where a drug product bears a tendency to associate with mucus membrane of gastric linings [3]. Single unit systems such as monolithic matrix tablets are more favourable because of their ease of the preparation and the large size of the dosage forms, which restricts rapid passage through gastric pylorus [4], whereas conventional sustained release formulation will quickly pass through the absorption window and reach the colon before releasing all the drug content in the stomach. Multiple administration leads to higher incidences of adverse effects, moreover conventional dosage form leads to higher occurances of fluctuation in plasma drug level $[5,6]$. Bioadhesive or mucoadhesive drug delivery systems involve the use of bioadhesive polymers, which adhere to the epithelial surface in the stomach. Intimate contact between the delivery system and mucosa improves both the effectiveness and efficiency of the delivery system [7].

\section{Applications of MGRDDS}

Mucoadhesive delivery system offers several merits over conventional drug delivery systems, which are listed herewith [8-10]:

a. Prolongs the residence time of the dosage form at the site of absorption, hence can increase the bioavailability.

b. Excellent accessibility, rapid onset of action possible.

c. Rapid absorption because of enormous blood supply and good perfusion rates.

d. The reduction in dosing frequency leads to improvement in patient compliance,.

e. Rapid cellular recovery and healing of the local site in case of ulcers.

f. Increased safety margin of high potency drugs due to control over drug's plasma levels.

g. Maximum utilization of drug enabling reduction in total amount of drug administered.

Following illustrations as mentioned in Table 1 signifies the role of MRGDDS technology application to wide variety of 
drug candidates. Most of the key drugs products utilizing this technology had been given marketing authorizations (Table 2).

Table 1: Potential drug candidates for MGRDDS.

\begin{tabular}{|c|c|}
\hline Drug Candidates & Examples \\
\hline $\begin{array}{c}\text { Drugs which act locally in } \\
\text { stomach }\end{array}$ & $\begin{array}{c}\text { Antacids, antiulcer drugs, } \\
\text { misoprostol, clarithromycin, } \\
\text { antibiotics like amoxicillin }\end{array}$ \\
\hline $\begin{array}{c}\text { Drugs with narrow absorption } \\
\text { window in GIT }\end{array}$ & $\begin{array}{c}\text { Para amino benzoic acid, } \\
\text { theophylline, methotrexate, } \\
\text { levodopa, riboflavin }\end{array}$ \\
\hline Drugs sensitive to pH & $\begin{array}{c}\text { Enalapril, ranitidine, captopril, } \\
\text { metformin hydrochloride }\end{array}$ \\
\hline $\begin{array}{c}\text { Drugs with low solubility at } \\
\text { alkaline pH }\end{array}$ & $\begin{array}{c}\text { Diazepam, furosemide, verapamil } \\
\text { hydrochloride }\end{array}$ \\
\hline
\end{tabular}

Table 2: Muccoadhesive gastroretentive formulations available in Market.

\begin{tabular}{|c|c|c|c|}
\hline Brand Name & $\begin{array}{c}\text { Active } \\
\text { Ingredient }\end{array}$ & Dosage Form & Manufacturer \\
\hline Cifran OD & Ciprofloxacin & Tablet & Ranbaxy, India \\
\hline Xifaxan & Rifaximin & Tablet & Lupin, India \\
\hline Cytotec & Misoprostal & Tablet & Pfizer, India \\
\hline Madopar & $\begin{array}{l}\text { L-DOPA and } \\
\text { Benserazide }\end{array}$ & Capsule & $\begin{array}{c}\text { Nicholas } \\
\text { Piramal , India }\end{array}$ \\
\hline Valrelease & Diazepam & Tablet & $\begin{array}{c}\text { Roche } \\
\text { Laboratories, } \\
\text { USA }\end{array}$ \\
\hline Topalkan & $\begin{array}{l}\text { Aluminum } \\
\text {-magnesium } \\
\text { antacid }\end{array}$ & Liquid alginate & $\begin{array}{l}\text { Pierre Fabre } \\
\text { drug, France }\end{array}$ \\
\hline Glumetza & $\begin{array}{c}\text { Metformin } \\
\text { hydrochloride }\end{array}$ & Tablet & $\begin{array}{l}\text { Depomed, } \\
\text { Canada }\end{array}$ \\
\hline
\end{tabular}

In last five years important innovations in GRDDS technology that lead to address the prevailing issues in drug delivery are given in Table 3.

Table 3: Patents technologies for GRDDS formulations

\begin{tabular}{|c|c|c|c|}
\hline Patent & Patent No. & Reference & $\begin{array}{c}\text { Year of } \\
\text { Publication }\end{array}$ \\
\hline $\begin{array}{c}\text { Gastroretentive drug } \\
\text { delivery system }\end{array}$ & $\begin{array}{c}\text { EP 1886665 } \\
\text { A1 }\end{array}$ & $\begin{array}{c}\text { Eisenreich } \\
\text { et al. [6] }\end{array}$ & 2009 \\
\hline $\begin{array}{c}\text { Novel Gastroretentive } \\
\text { dosage forms of poorly } \\
\text { soluble drugs }\end{array}$ & WO & Navon [12] & 2011 \\
\hline $\begin{array}{c}\text { Gastroretentive drug } \\
\text { delivery system } \\
\text { comprising an } \\
\text { extended hydratable } \\
\text { polymer }\end{array}$ & $\begin{array}{c}2011048494 \\
\text { A2 }\end{array}$ & & \\
\hline $\begin{array}{c}\text { Multi- unit } \\
\text { gastroretentive } \\
\text { pharmaceutical dosage } \\
\text { form comprising } \\
\text { microparticles }\end{array}$ & & & \\
\hline
\end{tabular}

\begin{tabular}{|c|c|c|c|}
\hline $\begin{array}{c}\text { Essential oil loaded } \\
\text { muccoadhesive } \\
\text { nano-composite } \\
\text { delivery system for } \\
\text { gastrointestinal system }\end{array}$ & $\begin{array}{c}\text { US 8586083 } \\
\text { B2 }\end{array}$ & $\begin{array}{c}\text { Mohammad } \\
{[10]}\end{array}$ & 2014 \\
\hline & $\begin{array}{c}\text { US 8778396 } \\
\text { B2 }\end{array}$ & $\begin{array}{c}\text { Pillay et al. } \\
{[14]}\end{array}$ & 2014 \\
\hline & $\begin{array}{c}\text { W0 } \\
2016108774 \\
\text { A1 }\end{array}$ & $\begin{array}{c}\text { Duyguet al. } \\
{[5]}\end{array}$ & 2016 \\
\hline
\end{tabular}

Patent no. EP 1886665 A1 describes development of a gastro retentive drug delivery system providing an extended residence time of the dosage form in the stomach preferably for more than 4 hours to improve the bioavailability and the duration of action of drugs using various polymers in the formulation. WO 2011048494 A2 patent disclosed a multi-layered gastroretentive dosage form for the controlled release of a poorly soluble drug in the gastrointestinal tract of a patient, which disintegrates and unfolds rapidly upon contact with the gastric juices. According to patent no. US 8586083 B2a gastroretentive formulation is manufactured by extrusion method. The use of extrusion enables the product to take many useful forms, which upon hydrationwill not pass out of the stomach and gastroretention is achieved. US 8778396 B2 patent relates an orally administrable, gastroretentive pharmaceutical dosage form which contains at least one pharmaceutically active ingredient and at least one polymeric adjuvant which will retain the dosage form in a selected region of the gastrointestinal tract for sufficient time for the pharmaceutically active ingredient to be released and absorbed. WO 2016108774 A1 describes an invention is related with eradication and/or prevention therapy of $H$. pylori by improving the drug release profiles of encapsulated essential oil within chitosan/nanoclay microspheres which could be retained in gastrointestinal system.

\section{Hypothetical View on MGRDDS}

Muccoadhesive dosage forms can be envisaged as model platform technology for the efficient delivery of various poorly soluble and low bioavailability drugs. A drug can be formulated in different dosage forms through cost effective techniques as done in the above mentioned patents and have applications from different angles including design and development of novel muccoadhesive agents for permeation enhancement through prolongation of residence time.

The extensive research in the direction of placing an importance to oral controlled drug delivery system is always a welcome step, due to its acceptability among major parts of the world due to economic considerations and ease of administration. Reducing the dosing frequency is not only helpful to those who are too occupied with higher chances of missing the dose, but also in case of geriatric patience. The aim of the clinician is to achieve steady state plasma concentration, whereas that of economist of the countries is to reduce the cost of treatment and healthcare 
bills. MGRDDS is a single answer to these important hurdles faced by healthcare scientists and professionals worldwide.

Additionally, MGRDDS have a vast potential for the future research with the influx of new drug molecules and issues related to drug delivery. The new drugs are mostly from BCS Class II or Class IV category, presenting challenges with respect to their bioavailability post administration with conventional systems.

Various issues faced with these new drug candidates include:

(a) Low solubility

(b) Fast gastric clearance

(c) Gastric degradation when submerged in medium

(d) Physical characteristic variability associated to conventional system

The above issues more or less lead to low bioavailability with given dosage form. Thus, in many cases specialized platform technology is required to be developed. The low solubility issues can be resolved with floating type gastro retentive dosage form, however such systems also display variable plasma drug levels due to gastric emptying factors. No two patients eat similar food and thus the gastric residence time may vary, and even in ideal state where patient eating similar food may display gastric fluctuations based on miscellaneous bio-factors such as acidity, gastric motility etc. Thus, in such states if we are able to render adherence characteristics to the dosage form, that might address such gastric emptying phenomenon. The conventional oral solid dosage forms present variability due to its physical attributes, such as disintegration time based on variable hardness of tablet or grade or quantity of disintegrating agent used in formulation composition. Other factors that contribute include, presence of binder, solubilizer, absorption enhancers in the formulation might lead to variable bioavailability. To simplify the case, we would like to answer key frequently asked questions that arises to formulation scientist while matter is related BE study and related variability:

Why variable bioavailability is an issue in present scenario? The answer to this question is that regulators seek set bioequivalence $(\mathrm{BE})$ criteria to be met mandatorily prior to any approval of marketing authorization of the drug product in the given region. Although, the regulator's requirements might vary from country to country, however, to meet the strict BE ranges, the product must be presented with tight quality target product profiles (QTPP).

How such QTPPs are set? The answer lies in relation to drug product dissolution profile where specified quantity of drug is allowed to be released in given period of time. This leads to controlling the release of the drug temporally, i.e. time based.

Is spatial control release product beneficial? This is an important question that is not answered by using normal monolithic or monolithic floating oral solid dosage form. Once such controlled release (CR) tablet is administered it might land up anywhere in the gastric lumen to initiate its journey to release and present the drug for absorption. Thus, drug's fate depends primarily over the quantity and quality of medium to which it is presented and gastric emptying time. Thus, the attempt to adhere the drug product would ensure the specification of drug in a given window of absorption or time for drug dissolution would reflect pronounced picture to overcome variability due to gastric motility and emptying rate [10-15].

\section{Conclusion}

The platform technologies related to MGRDDS are evident of utility not only in terms of plethora of opportunities available to innovate for improvement in existing product, and it is a tool to overcome bio-variability issues due to gastric physiology, physical attributes of conventional dosage forms by utilizing controlled drug delivery with respect to temporal and spatial approaches.

\section{References}

1. Choi BY, Park HJ, Hwang SJ, Park JB (2002) Preparation of alginate beads for floating drug delivery system: effects of $\mathrm{CO} 2$ gas-forming agents. Int J Pharm 239: 81-91.

2. Rouge N, Buri P, Doelke E (1996) Drug absorption sites in the gastrointestinal tract and dosage forms for site specific delivery. Int J Pharm 136: 117-139.

3. Gu JM, Robinson JR, Leung SH (1988) Binding of Acrylic Polymers to Mucin/Epithelial Surfaces: structure property relationships. Crit Rev Ther Drug Carr Syst 5: 21-67.

4. Mostafavi A, Emami J, Varshosaz J, Davies NM, Rezazadeh M (2011) Development of a prolonged release gastroretentive tablet formulation of Ciprofloxacin Hydrochloride: Pharmacokinetic characterization in healthy human volunteer. Int J Pharm 409: 128-136.

5. Ahuja S (1985) Analytical profiles of drug substances. Elsevier Publishers, London, England, 14: 527-547.

6. Han CH, Hsu AF, Hsu L, Hsioao C, Teng CLD (2005) Pharmaceutical dosage form having immediate \& controlled release properties that contain a GABA B receptor agonist. US patent 20050220873.

7. Bansal S, Bansal M, Shilakari G, Asthana A (2013) Gastroretentive drug delivery system: recent trends and advances. Inventi Rapid: Pharm Tech.

8. Alexander A, Ajazuddin S, Tripathi DK, Verma T, Maurya J, et al. (2011) Mechanism responsible for mucoadhesion of mucoadhesive drug delivery system: a review. Int J App Bio and Pharm Tech 2(1): 434-45.

9. Madhav NVS, Ojha A, Tyagi Y, Negi M (2014) Mucoadhesion: a novelistic platform for drug delivery system. Int J Pharm 2(9): 246-258.

10. Patel AR, Patel DA, Chaudhry SV (2011) Mucoadhesive buccal drug delivery system. Int J of Pharm and Life Sci 2(6): 848-856.

11. Duygu A, Funda T, Suna Seda G (2016) Essential oil loaded muccoadhesive nano-composite delivery system for gastrointestinal system. WO 2016108774 A1.

12. Eisenreich W, Friedl T, Haertter S (2009) Gastroretentive drug delivery system. EP 1886665 A1.

13. Mohammad H (2014) Gastroretentive drug delivery system comprising an extended hydratable polymer. US 8586083 B2. 
14. Pillay V, Choonara Y, Murphy C, Moonisami S (2014) Multiunit gastroretentive pharmaceutical dosage form comprising microparticles. US 8778396 B2.
15. Navon N (2011) Novel gastroretentive dosage forms of poorly soluble drugs. WO 2011048494 A2; 2011.

Your next submission with JuniperPublishers will reach you the below assets

- Quality Editorial service

- Swift Peer Review

- Reprints availability

- E-prints Service

- Manuscript Podcast for convenient understanding

- Global attainment for your research

- Manuscript accessibility in different formats

( Pdf, E-pub, Full Text, audio)

- Unceasing customer service

Track the below URL for one-step submission https://juniperpublishers.com/online-submission.php 